\title{
Case Report \\ Penile and Scrotal Strangulation due to Metal Rings: Case Reports and a Review of the Literature
}

\author{
Neel H. Patel ${ }^{D},{ }^{1}$ Ariel Schulman, ${ }^{2}$ Jonathan Bloom, ${ }^{3}$ Nikil Uppaluri, ${ }^{1}$ Michael Iorga, ${ }^{1}$ \\ Suraj Parikh, ${ }^{1}$ John Phillips, ${ }^{1}$ and Muhammad Choudhury ${ }^{1}$ \\ ${ }^{1}$ Department of Urology, New York Medical College, Valhalla, NY, USA \\ ${ }^{2}$ Department of Urology, Duke University Medical Center, Durham, NC, USA \\ ${ }^{3}$ Urologic Oncology Branch, National Cancer Institute, Bethesda, MD, USA
}

Correspondence should be addressed to Neel H. Patel; neelhpatel@gmail.com

Received 13 February 2018; Accepted 8 March 2018; Published 27 March 2018

Academic Editor: Farhang Rabbani

Copyright (c) 2018 Neel H. Patel et al. This is an open access article distributed under the Creative Commons Attribution License, which permits unrestricted use, distribution, and reproduction in any medium, provided the original work is properly cited.

Penile and scrotal entrapment from a metal ring placed at the base of the penis is a rare, but important clinical dilemma encountered in urology. Emergent presentation to the urologist, after ring placement far longer than safely practiced, risks ischemic and permanent injury to penile, scrotal, and intrascrotal structures. Treating urologists should be aware of the prevalence of metal ring use, their potential complications, and the surgical approach to their safe removal. We present two patients who were identified at our institution with strangulating injuries of retained penile rings. The first patient was a healthy, 43-year-old male with a metal ring retained for 24 hours that was safely removed with industrial bolt cutters. The second patient, a 74-year-old male, died as a result of sepsis from injuries secondary to penoscrotal ischemia after $>48$ hour ring retention despite prompt removal at emergent presentation. Although rare, sexual practices may include the use of penoscrotal rings. When retained, ischemic injury and edema may lead to strangulation. Emergent removal may require industrial equipment that is not within the confines of normal operating room tools. Tissue injury may be severe and sepsis life-threatening, even after ring removal.

\section{Introduction}

Penile ring strangulation as well as concomitant scrotal entrapment can present as a challenging urological emergency. Metal rings in theory increase penoscrotal engorgement during sexual activity. Detumescence may facilitate removal while nonremoval may lead to delayed detumescence, edema, and then the cycle of tissue injury with ischemia and necrosis [1]. Of these presentations, constricting ring injury may be more commonly associated with ring materials of plastic, Teflon, or rubber, which are more amenable to surgical removal. Some penile rings are composed of titanium/metallic alloy, of heavy density, and can withstand common management tactics [2]. Various techniques have been described for removing constricting devices including lubricants, coiled strings/gauze, needle aspiration, and cutting of the ring itself [2-5]. Here we report our approach to two cases of penile strangulation with different clinical presentations requiring surgical treatment.

\section{Case Presentation}

2.1. Case 1. A 43-year-old man with no significant medical or psychiatric history presented to our emergency room (ED) with a 24-hour history of strangulated penis. The patient had placed both his phallus and scrotum through a metallic ring for sexual enhancement and then was unable to remove the ring after intercourse. The ring measured $6 \mathrm{~cm}$ in diameter and it was $1 \mathrm{~cm}$ thick. The patient complained of lower abdominal pain and decreased sensation to his genitalia. On physical exam, the patient was found to have severe swelling of his penis and scrotum distal to the ring, which was placed at the base of these structures as seen in Figure 1. There remained approx. $1 \mathrm{~cm}$ of space between ring and edematous genitals, but no possibility of manual removal. No necrotic tissue could be appreciated.

Attempts by ED staff to remove the ring using lubrication and the finger ring-cutter were unsuccessful. Urology 


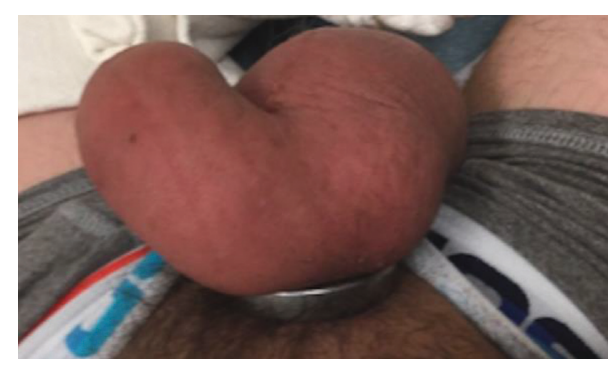

FIgURE 1: Case 1: metal ring encircling phallus and scrotum.

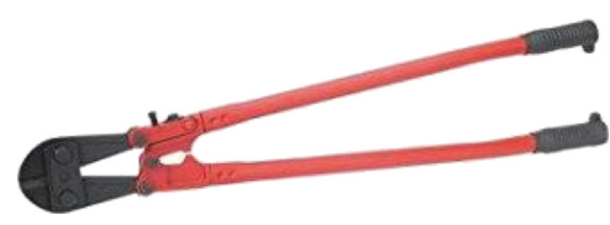

FIGURE 2: Industrial grade steel bolt cutters.

was then consulted, and the patient was taken to the Operating Room (OR) to receive general anesthesia to allow for more invasive removal options. Further attempts were made in the OR using an orthopedic pin cutter and gigli saw, which were limited. A handheld rotating electric saw was used and appeared to make progress; however, a high amount of heat was transmitted around the ring causing a first degree circumferential burn injury that could not be prevented despite use of irrigation during sawing to keep the ring cool. Industrial bolt cutters (Figure 2) were obtained from the maintenance department and were used to cut the ring at the 12 and 6 o'clock position, allowing for removal of the ring. Penile detumescence was achieved within the next hour, and the patient was discharged the following evening with oral antibiotics and pain control. One-week follow-up revealed that the patient had full recovery with good urinary and erectile function.

2.2. Case 2. A 74-year-old man presented to our ED with placement of a metal penoscrotal ring for over 48 hours. The patient had a history of multiple medical comorbidities including cirrhosis and diabetes mellitus. The patient was found by family and presented to the hospital in an obtunded state, with fevers, and an elevated white count. On physical exam, the patient was found to have ring placement at the base of his penis and scrotum. Severe swelling of the affected area was seen as shown in Figure 3(a). Due to the prolonged onset of presentation ( $>48$ hours), necrosis of the scrotum could be seen as well, as demonstrated in Figure 3(b). The patient was taken emergently to the OR and had removal of the ring with the use of bolt cutters with cuts in two separate parts allowing for removal of the device (Figure 3(c)). Despite aggressive resuscitation in the intensive care unit, the patient continued to be in septic shock postoperatively and died due to his condition.

\section{Discussion}

Penile strangulation presents as a urologic emergency usually brought on by the patient for enhancement of sexual function.

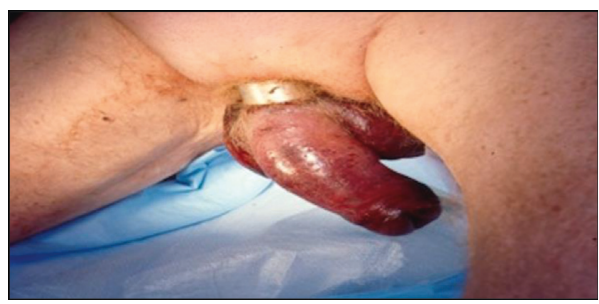

(a)

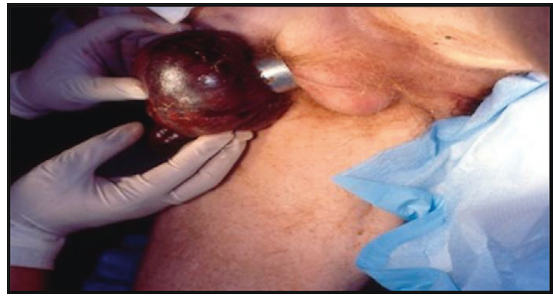

(b)

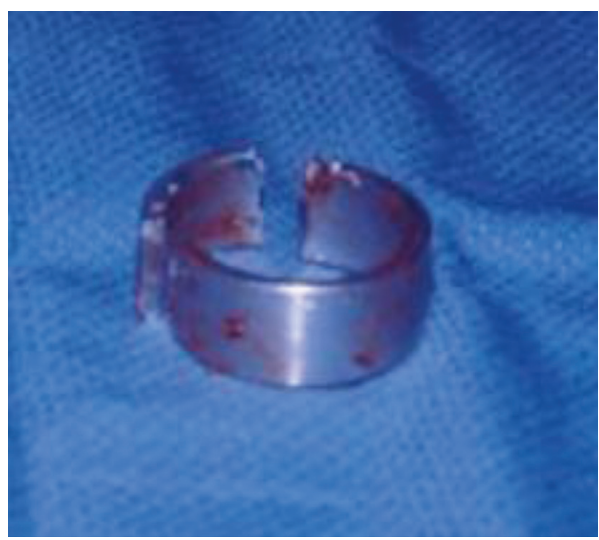

(c)

Figure 3: (a) Case 2: metal ring encircling phallus and scrotum. (b) Areas of significant necrosis seen along scrotum. (c) Metal ring disassembled with bolt cutters.

TABle 1: Penile strangulation classification system by Bhat et al.

\begin{tabular}{cc}
\hline Grade I & $\begin{array}{r}\text { Distal penis edema. No evidence of skin ulceration or } \\
\text { urethral injury. }\end{array}$ \\
Grade II & $\begin{array}{r}\text { Distal penile edema with decreased sensation. Injury } \\
\text { to skin, constriction of corpus spongiosum. No } \\
\text { urethral injury. }\end{array}$ \\
Grade III & $\begin{array}{r}\text { Injury to skin and urethra, without urethral fistula. } \\
\text { Loss of distal penile sensation. }\end{array}$ \\
Grade IV & $\begin{array}{r}\text { Complete division of corpus spongiosum leading to } \\
\text { urethral fistula and constriction of corpus } \\
\text { cavernosum with loss of distal penile sensation. } \\
\text { Gangrene, necrosis, or complete amputation of penis. }\end{array}$ \\
\hline
\end{tabular}

Presentation is often likely delayed due to embarrassment. Treatment requires prompt removal of the constricting device to allow for return of blood flow and relief of urinary obstruction. Early success with removal of the constricting ring will limit the ischemia time and subsequent sequelae of necrosis and loss of function, that is, erectile and urinary function. 
TABLE 2: Presentation of various case reports with penile strangulation injury.

\begin{tabular}{|c|c|c|c|c|c|c|}
\hline \multicolumn{7}{|c|}{ Review of reported cases } \\
\hline & $\begin{array}{c}\text { Time to } \\
\text { presentation }\end{array}$ & Comorbidities & Device & Penile condition & Removal technique & Long-term sequelae \\
\hline $\begin{array}{l}\text { Chennamsetty } \\
\text { et al. [7] }\end{array}$ & 9 days & None & $\begin{array}{l}7 \mathrm{~mm} \text { thick, alloy } \\
\text { ring }\end{array}$ & Skin necrosis & $\begin{array}{l}\text { Orthopedic pin } \\
\text { cutter }\end{array}$ & None \\
\hline Singh et al. [1] & 26 hours & None & $\begin{array}{l}\text { Metallic ball } \\
\text { bearing ring }\end{array}$ & Edema/discoloration & $\begin{array}{l}\text { Needle } \\
\text { aspiration/manual } \\
\text { decompression }\end{array}$ & None \\
\hline \multirow{2}{*}{ Talib et al. [2] } & 8 hours & $\begin{array}{c}\text { Erectile } \\
\text { dysfunction }\end{array}$ & $\begin{array}{l}2.5 \times 1.5 \mathrm{~cm} \\
\text { metallic ring }\end{array}$ & $\begin{array}{c}\text { Penile } \\
\text { edema/congestion }\end{array}$ & Rotating saw & None \\
\hline & 6 hours & None & $\begin{array}{l}1 \mathrm{~cm} \text { thick metal } \\
\text { ball bearing ring }\end{array}$ & Penile edema & 4 needle aspiration & None \\
\hline $\begin{array}{l}\text { Santucci et al. } \\
{[6]}\end{array}$ & 72 hours & Schizophrenia & $10 \mathrm{lb}$ barbell & $\begin{array}{c}\text { Penile } \\
\text { edema/discoloration }\end{array}$ & Air grinder saw & None \\
\hline Eaton et al. [8] & 16 hours & None & $\begin{array}{c}1 \mathrm{~cm} \text { thick } \times 2 \mathrm{~cm} \\
\text { wide } \times 6 \mathrm{~cm} \\
\text { diameter ring }\end{array}$ & $\begin{array}{c}\text { Penile } \\
\text { edema/hyperemia }\end{array}$ & Gigli saw & None \\
\hline Huang et al. [9] & - & $\begin{array}{l}\text { Diabetes } \\
\text { mellitus, } \\
\text { coronary } \\
\text { artery disease }\end{array}$ & Plastic bottle & Penile edema & Dental drill & None \\
\hline $\begin{array}{l}\text { Zhang et al. } \\
{[12]}\end{array}$ & 2 days & None & $\begin{array}{c}3 \mathrm{~cm} \\
\text { diameter } \times 2 \mathrm{~mm} \\
\text { thick metallic } \\
\text { ring }\end{array}$ & Penoscrotal edema & $\begin{array}{l}\text { Hydraulic cable } \\
\text { cutter }\end{array}$ & None \\
\hline Kyei et al. [10] & 12 hours & None & $\begin{array}{c}2 \mathrm{~cm} \\
\text { wide } \times 0.8 \mathrm{~cm} \\
\text { thick metallic nut }\end{array}$ & Penile edema & $\begin{array}{l}\text { Bosch electric } \\
\text { grinder }\end{array}$ & $\begin{array}{c}\text { Thermal } \\
\text { injury-urethrocutaneous } \\
\text { fistula and urethral } \\
\text { stricture }\end{array}$ \\
\hline $\begin{array}{l}\text { Morentin et al. } \\
{[11]}\end{array}$ & 2 weeks & $\begin{array}{l}\text { Cerebral } \\
\text { vascular } \\
\text { accident, } \\
\text { smoking, } \\
\text { alcoholism, } \\
\text { social } \\
\text { behavior } \\
\text { disorder }\end{array}$ & Plastic bottle & Necrosis/gangrene & None & $\begin{array}{c}\text { Death-multiorgan failure } \\
\text { due to sepsis }\end{array}$ \\
\hline
\end{tabular}

A five-stage grading system was developed by Bhat et al. to also help characterize these injuries [4]. The spectrum of severity on the Bhat scale ranged from Grade I causing edema of the distal penis, to Grade $\mathrm{V}$ presenting with gangrene, necrosis, or complete amputation (Table 1). Approaches to removal of constricting devices have a wide range of options, which can depend on the device composition and size, as well as degree of edema/strangulation. There have been reports demonstrating use of needle aspiration, electric tools, saws, industrial bolt cutters, and assistance from firemen and maintenance staff (Table 2) [1, 2, 6-12].

Our case presentations demonstrate multiple tactics progressing from simple emergency room options to a variety of tools that required use in a controlled setting within the operating room. We suggest the involvement of other individuals such as orthopedic or trauma surgery, the maintenance department, or even emergency or fire personnel for their knowledge of tools foreign to most urologists. Mechanical methods of device removal should be preferred over electrical/thermal devices to reduce the possibility of burn injury as well as urethrocutaneous fistulas or urethral strictures
[10]. The device should be cut in two places, ideally 180 degrees apart for easy removal. If electrical tools are required, then care must be taken to protect the underlying and adjacent tissue, as well as cool the device while cutting. Patients with extensive medical comorbidities and those at high risk for postoperative complications should be monitored appropriately and have adequate follow-up.

Our second case presentation demonstrates the possibility of death from penile strangulation due to concomitant sepsis and multiple medical comorbidities. To our knowledge, this is the second such reported incident. Morentin et al. initially presented death as a result of multiorgan failure due to septic shock in a patient with penile strangulation and multiple medical comorbidities from a plastic bottle for approximately two weeks [11].

\section{Conclusion}

Penile strangulation presents as a urological emergency, and if not managed in a timely fashion, it can lead to ischemic complications such as necrotic tissue or wounds or sexual 
and urinary dysfunction. Prolonged episodes in patients with multiple medical comorbidities can even result in death. Multiple methods of management have been presented in the literature. Tools unfamiliar to the surgeon and the assistance of other departments in an institution may be needed for prompt management and reduction of the strangulation. Mechanical methods of removal may be preferred to avoid any injury from thermal/electrical burns.

\section{Conflicts of Interest}

The authors declare that they have no conflicts of interest.

\section{References}

[1] I. Singh, M. K. Joshi, and M. S. Jaura, "Strangulation of penis by a ball bearing device," Journal of Sexual Medicine, vol. 7, no. 11, pp. 3793-3797, 2010.

[2] R. A. Talib, O. Canguven, A. Al Ansari, and A. Shamsodini, "Treatment of penile strangulation by the rotating saw and 4needle aspiration method: two case reports," Archivio Italiano di Urologia e Andrologia, vol. 86, no. 2, pp. 138-139, 2014.

[3] J. Silberstein, J. Grabowski, C. Lakin, and I. Goldstein, "Penile constriction devices: case report, review of the literature, and recommendations for extrication," Journal of Sexual Medicine, vol. 5, no. 7, pp. 1747-1757, 2008.

[4] A. L. Bhat, A. Kumar, S. C. Mathur, and K. C. Gangwal, "Penile strangulation," British Journal of Urology, vol. 68, no. 6, pp. 618-621, 1991.

[5] J. Peay, J. Smithson, J. Nelson, and P. Witucki, "Safe emergency department removal of a hardened steel penile constriction ring," Journal of Emergency Medicine, vol. 37, no. 3, pp. 287-289, 2009.

[6] R. A. Santucci, D. Deng, and J. Carney, "Removal of metal penile foreign body with a widely available emergencymedical-services-provided air-driven grinder," Urology, vol. 63, no. 6, pp. 1183-1184, 2004.

[7] A. Chennamsetty, D. Wenzler, and M. Fischer, "Removal of a penile constriction device with a large orthopedic pin cutter," Case Reports in Urology, vol. 2014, Article ID 347285, 3 pages, 2014.

[8] S. H. Eaton, R. J. Dickstein, and J. B. Wiygul, "Novel use of the Gigli saw for management of penile entrapment," Journal of Sexual Medicine, vol. 6, no. 2, pp. 595-597, 2009.

[9] J. K. Huang, D. Holt, and T. Philp, "Penile constriction by foreign bodies: the use of a dental drill," BJU International, vol. 79, no. 5, p. 801, 1997.

[10] M. Y. Kyei, E. K. Asante, J. E. Mensah et al., "Penile strangulation by self-placement of metallic nut," Ghana Medical Journal, vol. 49, no. 1, pp. 57-59, 2015.

[11] B. Morentin, B. Biritxinaga, and L. Crespo, "Penile strangulation: report of a fatal case," American Journal of Forensic Medicine and Pathology, vol. 32, no. 4, pp. 344-346, 2011.

[12] J. Zhang, X. Wang, Z. Li, J. Zhang, X. Zhang, and N. Xing, "Penoscrotal strangulation caused by a steel ring: a case report," Sexual Medicine, vol. 5, no. 2, pp. e131-e133, 2017. 


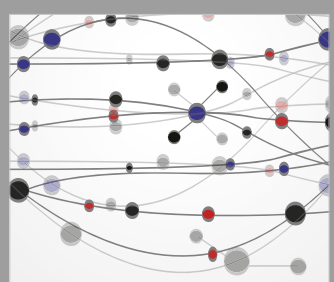

The Scientific World Journal
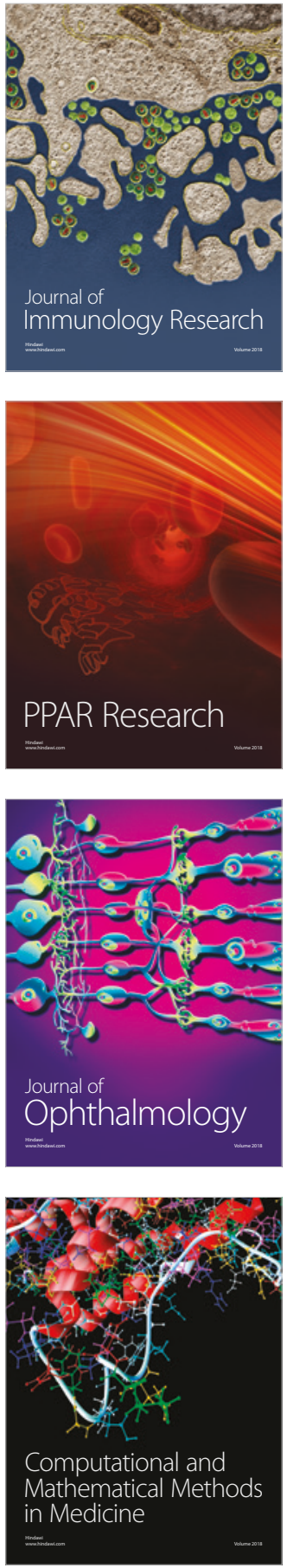

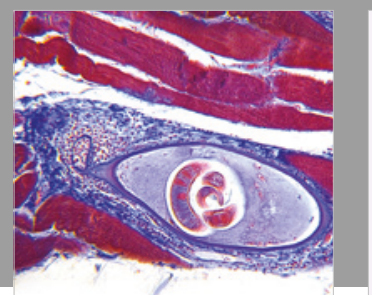

Gastroenterology Research and Practice

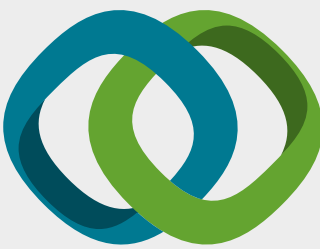

\section{Hindawi}

Submit your manuscripts at

www.hindawi.com
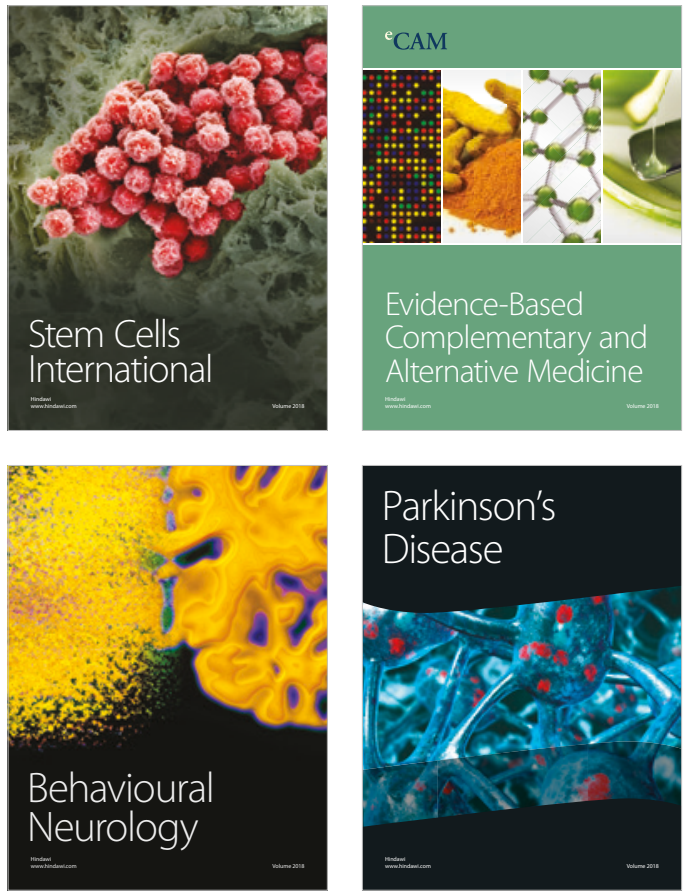

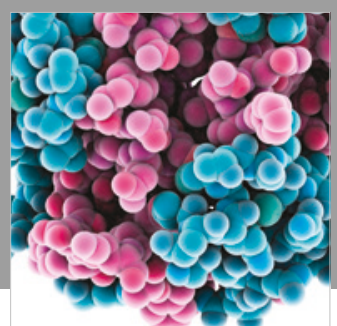

ournal of

Diabetes Research

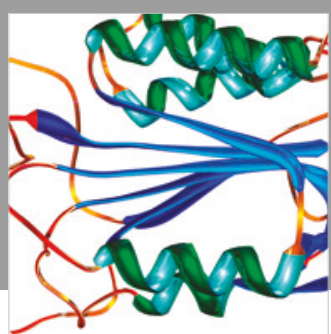

Disease Markers
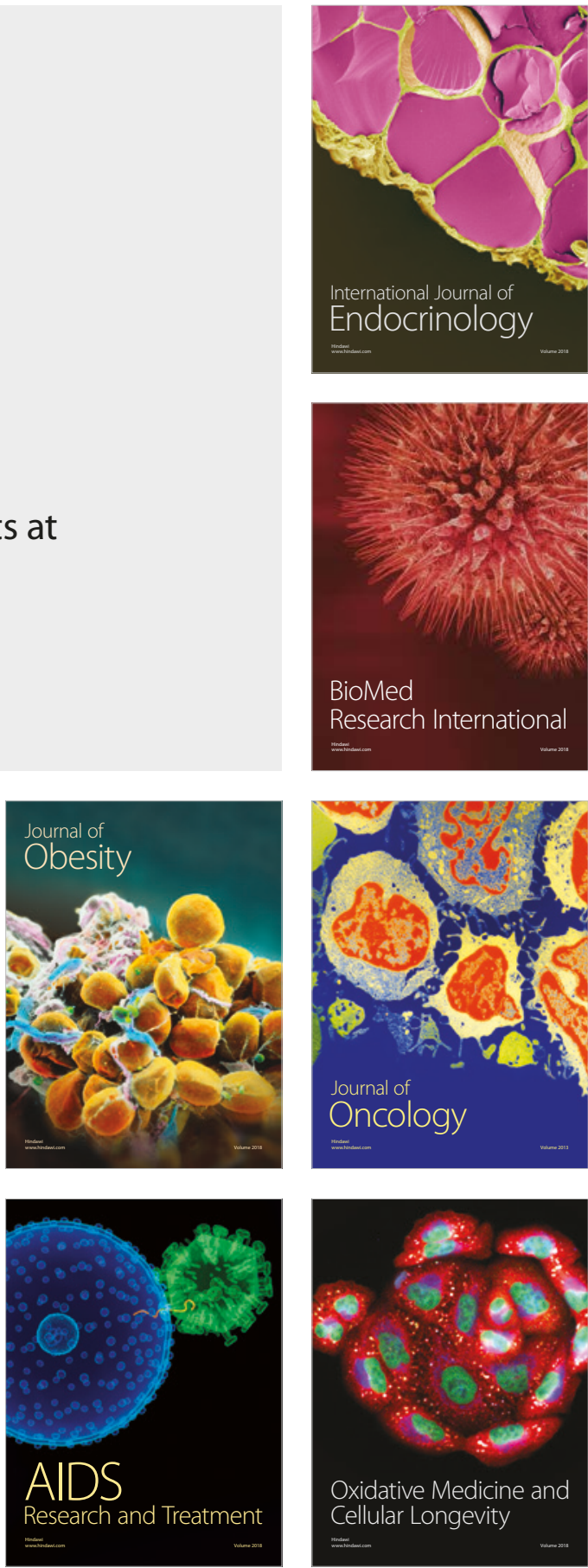